\title{
Energy-Level Control via Molecular Planarization and Its Effect on Interfacial Charge-Transfer Processes in Dye-Sensitized Solar Cells
}

Yifan Liu, ${ }^{\mathrm{a}, \mathrm{c}}$ Xiaomin Zhang, ${ }^{\mathrm{a}}$ Chen Li, ${ }^{\mathrm{b}}$ Yuqi Tian, ${ }^{\mathrm{a}}$ Fengyu Zhang, ${ }^{\mathrm{a}}$ Yajun

Wang, ${ }^{a}$ Wenjun $\mathrm{Wu},{ }^{* b}$ and $\mathrm{Bo} \mathrm{Liu}^{* \mathrm{a}}$

${ }^{a}$ Hebei Key Laboratory of Organic Functional Molecules, College of Chemistry and Material Science, Hebei Normal University, No. 20, East Road of Nan Er Huan, Shijiazhuang 050023, P. R. China. E-mail: liubo@hebtu.edu.cn;

${ }^{\mathrm{b}}$ Key Laboratory for Advanced Materials and Institute of Fine Chemicals, Shanghai Key Laboratory of Functional Materials Chemistry, School of Chemistry and Molecular Engineering, East China University of Science and Technology, 130 Meilong Road, Shanghai 200237, P. R. China. E-mail: wjwu@ecust.edu.cn

${ }^{\mathrm{c}}$ School of Pharmacy, Hebei Medical University, Shijiazhuang 050017, P. R. China 


\section{Synthetic details}

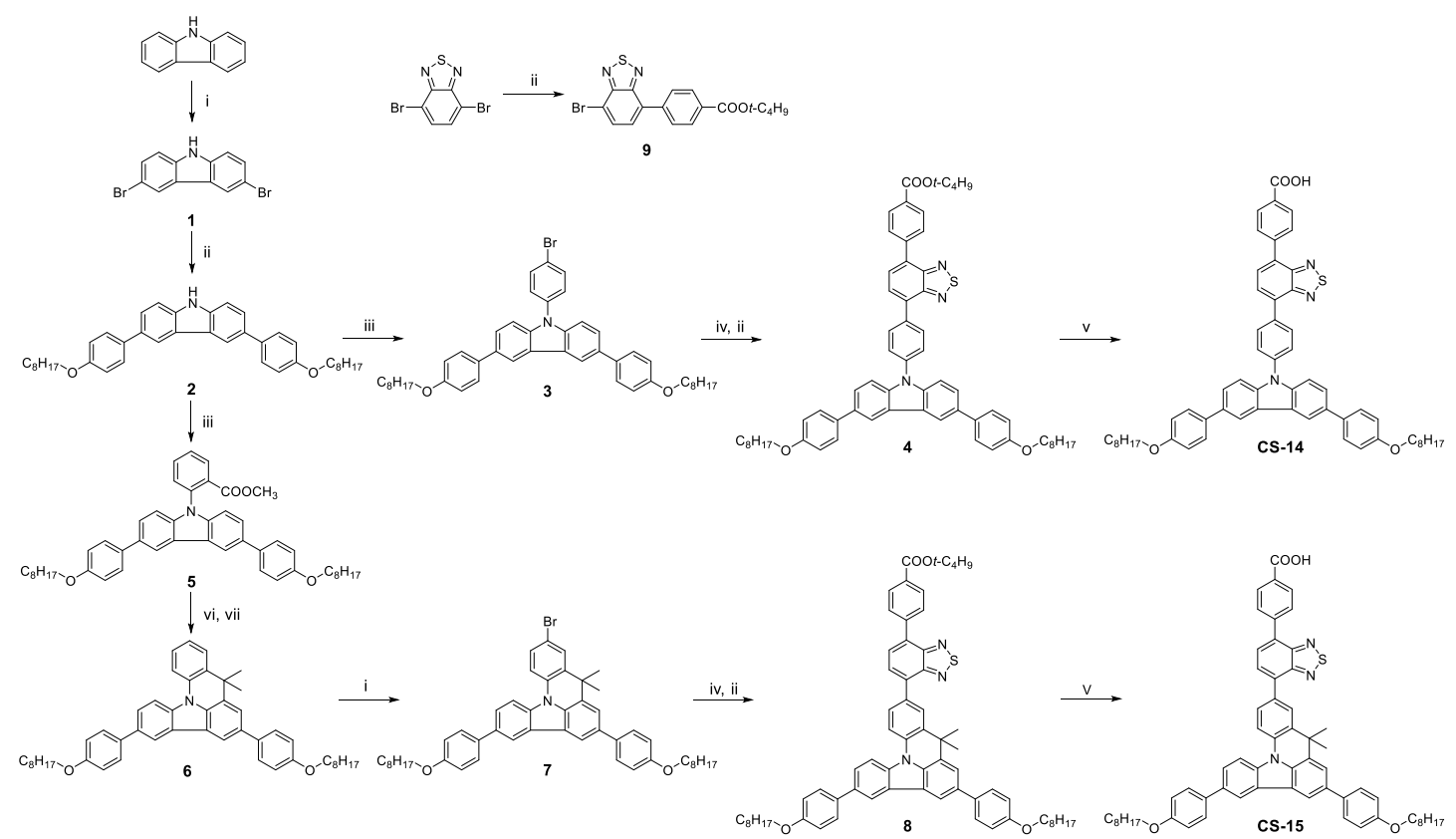

Scheme S1 Synthetic routs of dyes CS-14 and CS-15. Reaction conditions: i: NBS, THF; ii: $\mathrm{Pd}\left(\mathrm{PPh}_{3}\right)_{4}, 2 \mathrm{M} \mathrm{Na} \mathrm{CO}_{3}$, toluene; iii: $\mathrm{CuI}, \mathrm{Cs}_{2} \mathrm{CO}_{3}$, o-dichlorobenzene; iv: triisopropyl borate, $\mathrm{n}$-BuLi, THF; $\mathrm{v}$ : $\mathrm{CF}_{3} \mathrm{COOH}$, DCM; vi: methylmagnesium bromide, THF; vii: Amberlyst 15, toluene.

Synthesis of intermediate 1: The carbazole (5.00 g, $29.94 \mathrm{mmol})$ was dissolved in $\operatorname{THF}(150 \mathrm{ml})$, which was added a solution of $13.32 \mathrm{~g}$ of $\mathrm{N}$-bromosuccinimide dissolved in THF. The mixture was stirred for $4 \mathrm{~h}$ at room temperature in the darkness under nitrogen. After the reaction was completed, the mixture was evaporated and purified by column chromatography $(\mathrm{PE} / \mathrm{EA}=100: 1)$ on silica gel to yield the product as white solid (8.76 g, yield 90\%). ${ }^{1} \mathrm{H}$ NMR (500 MHz, $\left.\mathrm{CDCl}_{3}, \mathrm{ppm}\right): \delta 8.16(\mathrm{~s}, 2 \mathrm{H}), 8.09(\mathrm{~s}, 1 \mathrm{H}), 7.55(\mathrm{~d}, J=8.0 \mathrm{~Hz}, 2 \mathrm{H}), 7.33(\mathrm{~d}, J=$ $8.5 \mathrm{~Hz}, 2 \mathrm{H})$.

Synthesis of intermediate 2: The compound 1 (2.00 g, $6.15 \mathrm{mmol})$, (4(octyloxy)phenyl)boronic acid (3.77 g, $15.08 \mathrm{mmol}), 2 \mathrm{M} \mathrm{Na}_{2} \mathrm{CO}_{3}(5 \mathrm{~mL})$, and 
$\mathrm{Pd}\left(\mathrm{PPh}_{3}\right)_{4}(0.71 \mathrm{~g}, 0.61 \mathrm{mmol})$ were mixed in toluene $(31 \mathrm{ml})$. The mixture was refluxed for $24 \mathrm{~h}$ under nitrogen. After the reaction was completed, water was added and the reaction mixture was extracted with ethyl acetate. The organic layer was dried over anhydrous $\mathrm{Na}_{2} \mathrm{SO}_{4}$, and evaporated under reduced pressure. The crude product was purified by column chromatography $(\mathrm{PE} / \mathrm{EA}=100: 1)$ on silica gel to yield the product as white solid (2.66 g, yield $75.14 \%) .{ }^{1} \mathrm{H}$ NMR $\left(500 \mathrm{MHz}, \mathrm{CDCl}_{3}, \mathrm{ppm}\right): \delta 8.27(\mathrm{~s}, 2 \mathrm{H}), 8.06(\mathrm{~s}, 1 \mathrm{H}), 7.63(\mathrm{~d}, J=9.0 \mathrm{~Hz}, 6 \mathrm{H})$, $7.47(\mathrm{~d}, J=8.0 \mathrm{~Hz}, 2 \mathrm{H}), 7.01(\mathrm{~d}, J=8.5 \mathrm{~Hz}, 4 \mathrm{H}), 4.02(\mathrm{t}, J=7.0 \mathrm{~Hz}, 4 \mathrm{H}), 1.80-$ $1.85(\mathrm{~m}, 4 \mathrm{H}), 1.46-1.52(\mathrm{~m}, 4 \mathrm{H}), 1.31-1.38(\mathrm{~m}, 16 \mathrm{H}), 0.90(\mathrm{t}, J=7.0 \mathrm{~Hz}, 6 \mathrm{H})$.

Synthesis of intermediate 3: The intermediate 2 (1.00 g, $1.74 \mathrm{mmol})$, 1-bromo4-iodobenzene (0.98 g, $3.46 \mathrm{mmol}), \mathrm{CuI}(0.33 \mathrm{~g}, 1.74 \mathrm{mmol})$ and $\mathrm{Cs}_{2} \mathrm{CO}_{3}(1.13$ $\mathrm{g}, 3.46 \mathrm{mmol}$ ) were mixed in DMF (50 ml), The mixture was refluxed for $24 \mathrm{~h}$ under nitrogen. After the reaction was completed, then the reaction mixture was added to $\mathrm{CH}_{2} \mathrm{Cl}_{2}(200 \mathrm{ml})$, the mixture was then filtered. The filtrate was evaporated under reduced pressure. The crude product was purified by column chromatography $(\mathrm{PE} / \mathrm{EA}=500: 1)$ on silica gel to yield the product as white solid (1.14 g, yield 89.76\%). ${ }^{1} \mathrm{H}$ NMR (500 $\left.\mathrm{MHz}, \mathrm{CDCl}_{3}, \mathrm{ppm}\right): \delta 8.35$ (s, 2H), 7.98 $(\mathrm{d}, J=8.5 \mathrm{~Hz}, 1 \mathrm{H}), 7.78(\mathrm{~d}, J=8.5 \mathrm{~Hz}, 1 \mathrm{H}), 7.65(\mathrm{t}, J=7.0 \mathrm{~Hz}, 6 \mathrm{H}), 7.53(\mathrm{~d}, J$ $=8.5 \mathrm{~Hz}, 1 \mathrm{H}), 7.44-7.47(\mathrm{~m}, 2 \mathrm{H}), 7.40(\mathrm{~d}, J=8.5 \mathrm{~Hz}, 1 \mathrm{H}), 7.05(\mathrm{t}, J=8.5 \mathrm{~Hz}$, 4H), $4.05(\mathrm{t}, J=6.5 \mathrm{~Hz}, 4 \mathrm{H}), 1.83-1.88(\mathrm{~m}, 4 \mathrm{H}), 1.49-1.55(\mathrm{~m}, 4 \mathrm{H}), 1.34-1.41$ $(\mathrm{m}, 16 \mathrm{H}), 0.93(\mathrm{t}, J=7.0 \mathrm{~Hz}, 6 \mathrm{H})$. 
Synthesis of intermediate 9: The intermediate 9 was synthesized according to the published procedure. ${ }^{1}$

Synthesis of intermediate 4: The compound $3(0.34 \mathrm{~g}, 0.46 \mathrm{mmol})$ in dry THF (25 ml) was cooled to $-78{ }^{\circ} \mathrm{C}$ under nitrogen. Then the $\mathrm{n}$-BuLi (3ml) was slowly dropped and the mixture was stirred for $2 \mathrm{~h}$. The triisopropyl borate $(0.26 \mathrm{~g}, 1.38$ mmol) was slowly dropped and the mixture was stirred for another $1 \mathrm{~h}$ at $-78{ }^{\circ} \mathrm{C}$ and $12 \mathrm{~h}$ at r.t., respectively. After the reaction was completed, water was added and the reaction mixture was extracted with ethyl acetate. The combined organic layer was dried over anhydrous $\mathrm{Na}_{2} \mathrm{SO}_{4}$ and the solvent was evaporated under reduced pressure. Then $2 \mathrm{M} \mathrm{K}_{2} \mathrm{CO}_{3}(4 \mathrm{ml})$, compound $9(0.20 \mathrm{~g}, 0.51 \mathrm{mmol})$, $\mathrm{Pd}\left(\mathrm{PPh}_{3}\right)_{4}(0.05 \mathrm{~g}, 0.043 \mathrm{mmol})$, and toluene $(30 \mathrm{ml})$ were added. The mixture was refluxed for $12 \mathrm{~h}$ under nitrogen. After cooling, water was added and the reaction mixture was extracted with ethyl acetate. The combined organic layer was dried over anhydrous $\mathrm{Na}_{2} \mathrm{SO}_{4}$ and evaporated under reduced pressure. The crude product was purified by column chromatography $(\mathrm{PE} / \mathrm{EA}=100: 1)$ on silica gel to yield the product as orange solid $(0.14 \mathrm{~g}$, yield $31.11 \%) .{ }^{1} \mathrm{H}$ NMR (500 MHz, DMF, ppm): $\delta 8.93(\mathrm{~s}, 2 \mathrm{H}), 8.67(\mathrm{~d}, J=8.0 \mathrm{~Hz}, 2 \mathrm{H}), 8.46(\mathrm{~d}, J=8.0 \mathrm{~Hz}$, $2 \mathrm{H}), 8.42(\mathrm{~d}, J=7.0 \mathrm{~Hz}, 1 \mathrm{H}), 8.36(\mathrm{~d}, J=8.0 \mathrm{~Hz}, 3 \mathrm{H}), 8.16(\mathrm{~s}, 2 \mathrm{H}), 8.00(\mathrm{~d}, J=$ $8.0 \mathrm{~Hz}, 6 \mathrm{H}), 7.83(\mathrm{~d}, J=8.0 \mathrm{~Hz}, 2 \mathrm{H}), 7.30(\mathrm{~d}, J=8.0 \mathrm{~Hz}, 4 \mathrm{H}), 4.26(\mathrm{t}, J=6.0$ $\mathrm{Hz}, 4 \mathrm{H}), 1.95-2.01(\mathrm{~m}, 4 \mathrm{H}), 1.82(\mathrm{~s}, 9 \mathrm{H}), 1.64-1.70(\mathrm{~m}, 4 \mathrm{H}), 1.48-1.57(\mathrm{~m}, 16 \mathrm{H})$, $1.06(\mathrm{t}, J=6.5 \mathrm{~Hz}, 6 \mathrm{H}) .{ }^{13} \mathrm{C} \mathrm{NMR}\left(100 \mathrm{MHz}, \mathrm{CDCl}_{3}, \mathrm{ppm}\right): \delta 165.5,158.3,154.0$, 
$141.2,136.1,134.2,133.0,132.7,131.8,130.8,129.8,129.1,128.6,128.3,124.2$, $118.4,114.9,81.2,68.2,31.9,29.4,29.4,29.3,28.3,26.1,22.7,14.2$.

Synthesis of CS-14: The compound $4(0.14 \mathrm{~g}, 0.145 \mathrm{mmol})$ was dissolved in $\mathrm{CH}_{2} \mathrm{Cl}_{2}(10 \mathrm{ml})$ and $\mathrm{CF}_{3} \mathrm{COOH}(2 \mathrm{~mL})$ was added. The mixture was stirred at room temperature for $3 \mathrm{~h}$. After the reaction was completed, water was added and the reaction mixture was extracted with $\mathrm{CH}_{2} \mathrm{Cl}_{2}$. The combined organic layer was dried over anhydrous $\mathrm{Na}_{2} \mathrm{SO}_{4}$ and evaporated under reduced pressure. The crude product was purified by column chromatography $(\mathrm{DCM} / \mathrm{MeOH}=100: 1)$ on silica gel to yield the product as orange solid (0.11 g, yield 84.62\%). ${ }^{1} \mathrm{H}$ NMR (500 MHz, DMF, ppm): $\delta 8.72(\mathrm{~s}, 2 \mathrm{H}), 8.52(\mathrm{~d}, J=8.0 \mathrm{~Hz}, 2 \mathrm{H}), 8.25-8.31(\mathrm{~m}$, 4H), $8.21(\mathrm{~d}, J=7.0 \mathrm{~Hz}, 1 \mathrm{H}), 7.99(\mathrm{~s}, 4 \mathrm{H}), 7.82(\mathrm{~d}, J=8.5 \mathrm{~Hz}, 5 \mathrm{H}), 7.66(\mathrm{~d}, J=$ $8.5 \mathrm{~Hz}, 2 \mathrm{H}), 7.13(\mathrm{~d}, J=8.0 \mathrm{~Hz}, 4 \mathrm{H}), 4.11(\mathrm{t}, J=6.0 \mathrm{~Hz}, 4 \mathrm{H}), 1.80-1.85(\mathrm{~m}, 4 \mathrm{H})$, 1.49-1.58 (m, 4H), 1.27-1.46 (m, 16H), $0.91(\mathrm{t}, J=7.0 \mathrm{~Hz}, 6 \mathrm{H}) .{ }^{13} \mathrm{C}$ NMR (125MHz, DMSO, ppm): $\delta$ 158.4, 153.9, 153.8, 153.8, 140.0, 136.1, 133.5, 133.0, 132.6, 131.4, 130.0, 129.8, 129.8, 129.6, 129.0, 128.2, 126.9, 125.5, 124.4, $115.4,68.0,56.5,31.7,29.2,29.2,29.2,26.0,22.6,19.0,14.4$.

Synthesis of intermediate 5: The compound 2 (4.32 g, $7.50 \mathrm{mmol})$, methyl 2bromobenzoate (1.61 g, $7.49 \mathrm{mmol}), \mathrm{CuI}(1.43 \mathrm{~g}, 7.50 \mathrm{mmol}), \mathrm{Cs}_{2} \mathrm{CO}_{3}(1.13 \mathrm{~g}$, $3.46 \mathrm{mmol})$ were dissolved in $o$-dichlorobenzene $(50 \mathrm{ml})$. The mixture was refluxed for $24 \mathrm{~h}$ under nitrogen. After the reaction was completed, the solvent was distilled off under reduced pressure. Then the reaction mixture was added to $\mathrm{CH}_{2} \mathrm{Cl}_{2}(200 \mathrm{ml})$ and filtered. The filtrate was evaporated under reduced pressure. 
The crude product was purified by column chromatography $(\mathrm{PE} / \mathrm{EA}=100: 1)$ on silica gel to yield the product as yellow solid (3.72 g, yield 70\%). ${ }^{1} \mathrm{H}$ NMR (500 $\left.\mathrm{MHz}, \mathrm{CDCl}_{3}, \mathrm{ppm}\right): \delta 8.36(\mathrm{~s}, 2 \mathrm{H}), 8.17(\mathrm{~d}, J=8.0 \mathrm{~Hz}, 1 \mathrm{H}), 7.80(\mathrm{~d}, J=7.5 \mathrm{~Hz}$, 1H), 7.61-7.68 (m, 8H), $7.20(\mathrm{~d}, J=8.5 \mathrm{~Hz}, 2 \mathrm{H}), 7.05(\mathrm{~d}, J=8.5 \mathrm{~Hz}, 4 \mathrm{H}), 4.06$ $(\mathrm{t}, J=6.5 \mathrm{~Hz}, 4 \mathrm{H}), 3.32(\mathrm{~s}, 3 \mathrm{H}), .1 .83-1.89(\mathrm{~m}, 4 \mathrm{H}), 1.51-1.54(\mathrm{~m}, 4 \mathrm{H}), 1.35-$ $1.42(\mathrm{~m}, 16 \mathrm{H}), 0.94(\mathrm{t}, J=6.5 \mathrm{~Hz}, 6 \mathrm{H})$.

Synthesis of intermediate 6: The intermediate $5(3.50 \mathrm{~g}, 4.93 \mathrm{mmol})$ and methylmagnesium bromide in THF $(15 \mathrm{ml})$ were mixed and refluxed for $12 \mathrm{~h}$ under nitrogen. After cooling to room temperature, saturated $\mathrm{NH}_{4} \mathrm{Cl}(100 \mathrm{ml})$ was added and the mixture was extracted with ethyl acetate. The crude product was obtained by evaporating the solvent under reduced pressure.

The above obtained crude product dissolved in toluene $(30 \mathrm{ml})$ was added Amberlyst 15 (1.50 g). The mixture was refluxed for $12 \mathrm{~h}$ under nitrogen. After cooling, the mixture was filtered to remove catalyst, then the filtrate was evaporated under reduced pressure. The crude product was purified by column chromatography $(\mathrm{PE} / \mathrm{EA}=300: 1)$ on silica gel to yield the product as yellow solid (2.46 g, yield 77.85\%). ${ }^{1} \mathrm{H}$ NMR (500 $\left.\mathrm{MHz}, \mathrm{CDCl}_{3}, \mathrm{ppm}\right): \delta 8.33(\mathrm{~s}, 1 \mathrm{H})$, $8.19(\mathrm{~d}, J=8.5 \mathrm{~Hz}, 1 \mathrm{H}), 8.11(\mathrm{~d}, J=8.0 \mathrm{~Hz}, 1 \mathrm{H}), 8.08(\mathrm{~s}, 1 \mathrm{H}), 7.75(\mathrm{~d}, J=7.0$ $\mathrm{Hz}, 1 \mathrm{H}), 7.64-7.68(\mathrm{~m}, 6 \mathrm{H}) 7.39(\mathrm{t}, J=7.5 \mathrm{~Hz}, 1 \mathrm{H}), 7.19(\mathrm{t}, J=7.5 \mathrm{~Hz}, 1 \mathrm{H}), 7.04$ $(\mathrm{d}, J=8.5 \mathrm{~Hz}, 4 \mathrm{H}), 4.04(\mathrm{t}, J=6.5 \mathrm{~Hz}, 4 \mathrm{H}), 1.82-1.86(\mathrm{~m}, 4 \mathrm{H}), 1.80(\mathrm{~s}, 6 \mathrm{H})$, $1.47-1.52(\mathrm{~m}, 4 \mathrm{H}), 1.32-1.37(\mathrm{~m}, 16 \mathrm{H}), 0.91(\mathrm{t}, J=7.0 \mathrm{~Hz}, 6 \mathrm{H})$. 
Synthesis of intermediate 7: The compound $6(0.12 \mathrm{~g}, 0.17 \mathrm{mmol})$ dissolved in $\mathrm{CH}_{2} \mathrm{Cl}_{2}(10 \mathrm{ml})$ was added a solution of $0.04 \mathrm{~g}$ of NBS dissolved in acetonitrile $(3 \mathrm{ml})$. The mixture was stirred for $4 \mathrm{~h}$ at $0^{\circ} \mathrm{C}$ under nitrogen and then the reaction mixture was poured into water and extracted with $\mathrm{CH}_{2} \mathrm{Cl}_{2}$. The organic layer was dried over anhydrous $\mathrm{Na}_{2} \mathrm{SO}_{4}$ and evaporated under reduced pressure. The crude product was purified by column chromatography $(\mathrm{PE} / \mathrm{EA}=200: 1)$ on silica gel to yield the product as white solid (0.10 g, yield 76.92\%). ${ }^{1} \mathrm{H}$ NMR (400 MHz, $\left.\mathrm{CDCl}_{3}, \mathrm{ppm}\right): \delta 9.19(\mathrm{~s}, 1 \mathrm{H}), 8.19(\mathrm{~d}, J=9.0 \mathrm{~Hz}, 1 \mathrm{H}), 8.05(\mathrm{~d}, J=9.0 \mathrm{~Hz}, 1 \mathrm{H})$, $7.85(\mathrm{~d}, J=7.0 \mathrm{~Hz}, 1 \mathrm{H}), 7.76(\mathrm{~s}, 1 \mathrm{H}), 7.72(\mathrm{~d}, J=9.0 \mathrm{~Hz}, 2 \mathrm{H}), 7.53(\mathrm{~d}, J=6.0$ $\mathrm{Hz}, 1 \mathrm{H}), 7.47(\mathrm{t}, J=8.0 \mathrm{~Hz}, 3 \mathrm{H}), 7.07(\mathrm{t}, J=8.0 \mathrm{~Hz}, 5 \mathrm{H}), 4.09(\mathrm{t}, J=6.0 \mathrm{~Hz}$, 4H), 1.86-1.91 (m, 4H), $1.77(\mathrm{~s}, 6 \mathrm{H}), 1.52-1.55(\mathrm{~m}, 4 \mathrm{H}), 1.35-1.40(\mathrm{~m}, 16 \mathrm{H})$, $0.95(\mathrm{t}, J=7.0 \mathrm{~Hz}, 6 \mathrm{H})$.

Synthesis of intermediate 8 and CS-15: The synthesis procedures of intermediate 8 and dye CS-15 were exactly same as those of intermediate 4 and dye CS-14.

Intermediate 8: ${ }^{1} \mathrm{H} \mathrm{NMR}\left(500 \mathrm{MHz}, \mathrm{CDCl}_{3}, \mathrm{ppm}\right): \delta 8.36(\mathrm{~s}, 2 \mathrm{H}), 8.21-8.25(\mathrm{~m}$, 4H), $8.12(\mathrm{~s}, 1 \mathrm{H}), 8.08(\mathrm{~d}, J=8.5 \mathrm{~Hz}, 2 \mathrm{H}), 8.02(\mathrm{~d}, J=6.5 \mathrm{~Hz}, 1 \mathrm{H}), 7.87(\mathrm{~s}, 2 \mathrm{H})$, $7.78(\mathrm{~d}, J=7.0 \mathrm{~Hz}, 1 \mathrm{H}), 7.68-7.72(\mathrm{~m}, 5 \mathrm{H}), 7.06-7.08(\mathrm{~m}, 4 \mathrm{H}), 4.07(\mathrm{t}, J=8.0$ Hz, 4H), 1.92 (s, 6H), 1.84-1.90 (m, 4H), 1.69 (s, 9H), 1.51-1.57 (m, 4H), 1.35$1.44(\mathrm{~m}, 16 \mathrm{H}), 0.95(\mathrm{t}, J=7.0 \mathrm{~Hz}, 6 \mathrm{H}) .{ }^{13} \mathrm{C} \mathrm{NMR}\left(125 \mathrm{MHz}, \mathrm{CDCl}_{3}, \mathrm{ppm}\right): \delta$ 165.6, 158.6, 158.5, 154.1, 154.1, 141.4, 137.5, 136.2, 136.0, 135.2, 134.7, 134.5, $134.1,133.7,133.5,131.8,131.6,129.7,129.6,129.0,128.8,128.6,128.4,128.2$, 
$128.1,127.0,126.9,125.5,122.7,121.4,118.9,115.9,115.0,114.9,114.1,113.8$, $81.1,68.2,68.2,37.1,33.3,31.9,29.7,29.5,29.4,29.3,28.3,26.1,22.7,14.2$.

CS-15: ${ }^{1} \mathrm{H}$ NMR (500 MHz, DMF, ppm): $\delta 8.76$ (s, 1H), 8.64 (s, 1H), 8.52-8.54 (m, 2H), $8.48(\mathrm{~d}, J=8.5 \mathrm{~Hz}, 1 \mathrm{H}), 8.21-8.29(\mathrm{~m}, 6 \mathrm{H}), 8.15(\mathrm{~d}, J=7.5 \mathrm{~Hz}, 1 \mathrm{H}), 7.99$ (s, 1H), $7.95(\mathrm{~d}, J=8.5 \mathrm{~Hz}, 1 \mathrm{H}), 7.87(\mathrm{t}, J=8.0 \mathrm{~Hz}, 4 \mathrm{H}), 7.13(\mathrm{~d}, J=8.0 \mathrm{~Hz}$, 4H), $4.09(\mathrm{t}, J=7.5 \mathrm{~Hz}, 4 \mathrm{H}), 1.98(\mathrm{~s}, 6 \mathrm{H}), 1.79-1.83(\mathrm{~m}, 4 \mathrm{H}), 1.49-1.51(\mathrm{~m}, 4 \mathrm{H})$, $1.30-1.43(\mathrm{~m}, 16 \mathrm{H}), 0.89(\mathrm{t}, J=7.0 \mathrm{~Hz}, 6 \mathrm{H}) .{ }^{13} \mathrm{C} \mathrm{NMR}(125 \mathrm{MHz}, \mathrm{DMF}, \mathrm{ppm})$ : $\delta 167.6,158.8,158.8,154.1,154.0,141.6,137.4,136.1,135.8,134.9,134.6$, $134.3,133.9,133.3,133.0,132.1,131.2,131.0,130.1,129.9,129.6,129.4,128.7$ $128.4,128.1,127.8,127.1,125.6,123.0,121.6,119.1,116.2,115.2,115.1,114.5$, $114.3,68.1,37.2,33.3,31.9,26.2,22.7,13.9$.

\section{Experimental details}

$J-V$ curves were obtained by using an AM 1.5 solar simulator equipped with a $150 \mathrm{~W}$ xenon lamp (OTENTO-SUN II, Bunkoukeiki Co., Ltd) as the light source. The power was calibrated to $100 \mathrm{~mW} \mathrm{~cm}{ }^{-2}$ using a reference silicon cell (BS-520, Bunkoukeiki Co., Ltd). The photocurrent action spectra were measured with a monochromator (M10T, Bunkoukeiki Co., Ltd). The intensity of monochromic light was calibrated by a reference silicon cell (S1337-1010BQ, Bunkoukeiki Co., Ltd).

The electrochemical impedance spectroscopy (EIS) measurements were characterized with Impedance Analyzer (ZAHNER-Elektrik GmbH \& CoKG, Kronach, Germany), with a frequency range of $0.1 \mathrm{~Hz}-100 \mathrm{kHz}$ and an alternative signal of 5 
$\mathrm{mV}$ at a constant temperature of $25^{\circ} \mathrm{C}$ in the dark conditions. The spectra were characterized using Zsimpwin software.

The charge lifetime and charge density in the complete DSSCs were measured by the stepped light-induced transient measurements of photocurrent and voltage (SLIM-PCV) of the photocurrent and voltage using PSL-100 (EKO Co. Ltd.). ${ }^{2}$ A laser $(\lambda=473 \mathrm{~nm})$ was used as the light source. The transients were induced by a stepwise change in the laser intensity which was controlled by adjusting its voltage. The photocurrent and photovoltage transients were monitored using a digital oscilloscope through an amplifier. Through varying the laser intensity, the lifetime could be estimated over a range of open-circuit voltages by fitting a decay of the photovoltage transient with $\exp (-$ $\mathrm{t} / \tau){ }^{2}$ The electron density measurements were performed as follows: the DSSC was illuminated for $5 \mathrm{~s}$ while a bias voltage was applied to make the cell open-circuit, then the laser as shut down simultaneously, and the cell was switched from open to short circuit. The resulting current was measured over $25 \mathrm{~s}$ and then the electron density could be calculated through integrating the electric charge. All experiments were conducted at room temperature. Ten samples were fabricated and tested for each measurement and median values were selected to be shown in this paper.

All the theoretical calculation analysis was performed using Gaussian 09 program. $^{3}$ The ground-state geometries of the dyes were optimized on the basis of hybrid density functional theory (B3LYP) with the 6-311G(d,p) basis set. TDDFT excited states calculation and the molecular geometries of both dyes at the first excited singlet states 
were performed at the MPWPW91/6-311G (d,p) level with the optimized ground-state geometry. Solvation effects (chloroform) were taken into account in the TDDFT calculations with the CPCM model implemented in Gaussian 09 program.

\section{Figures}

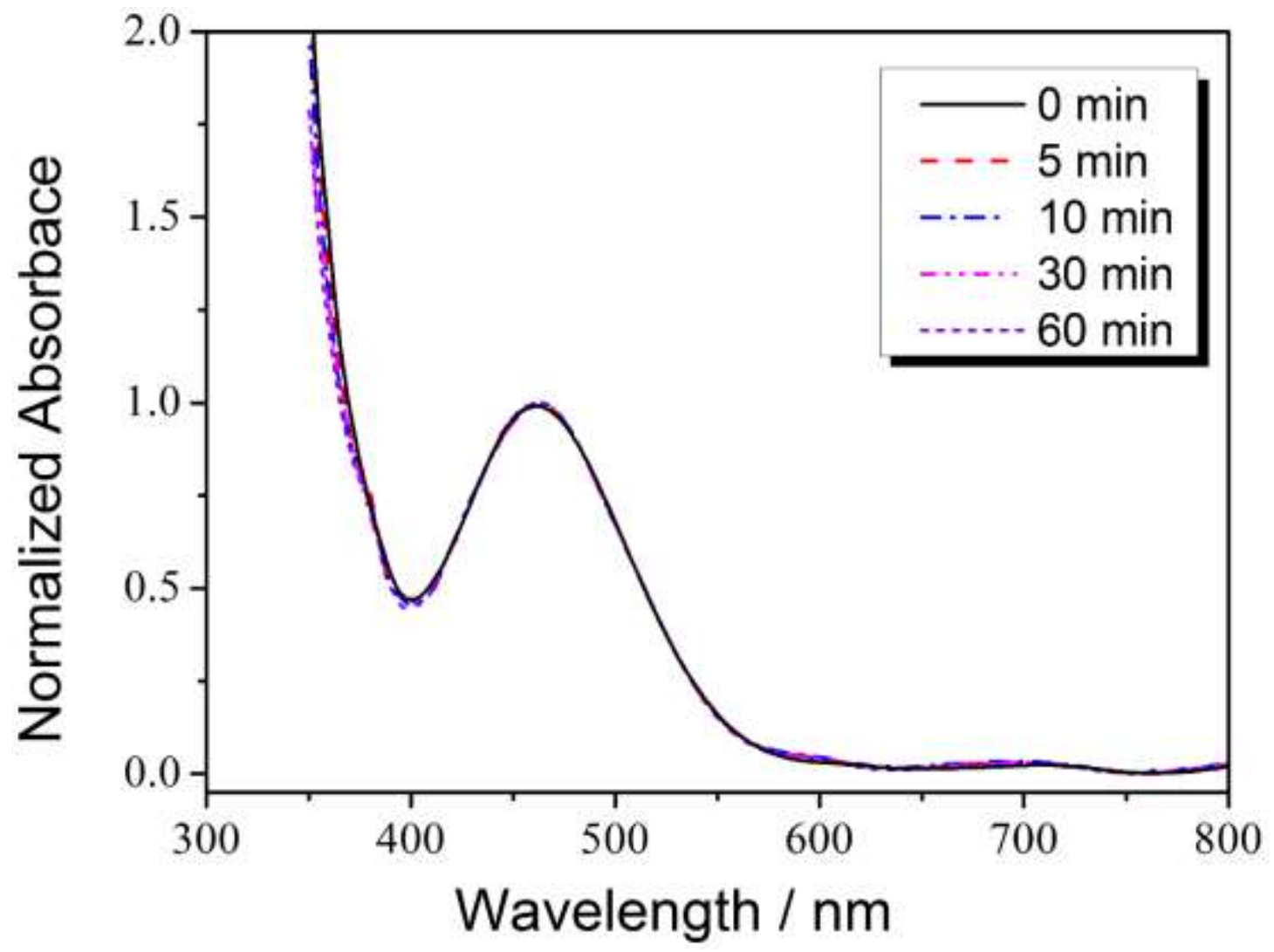

Figure S1 Photostability test of CS-15 sensitized $\mathrm{TiO}_{2}$ by soaking under Xe light for 0 to 60 minutes. 


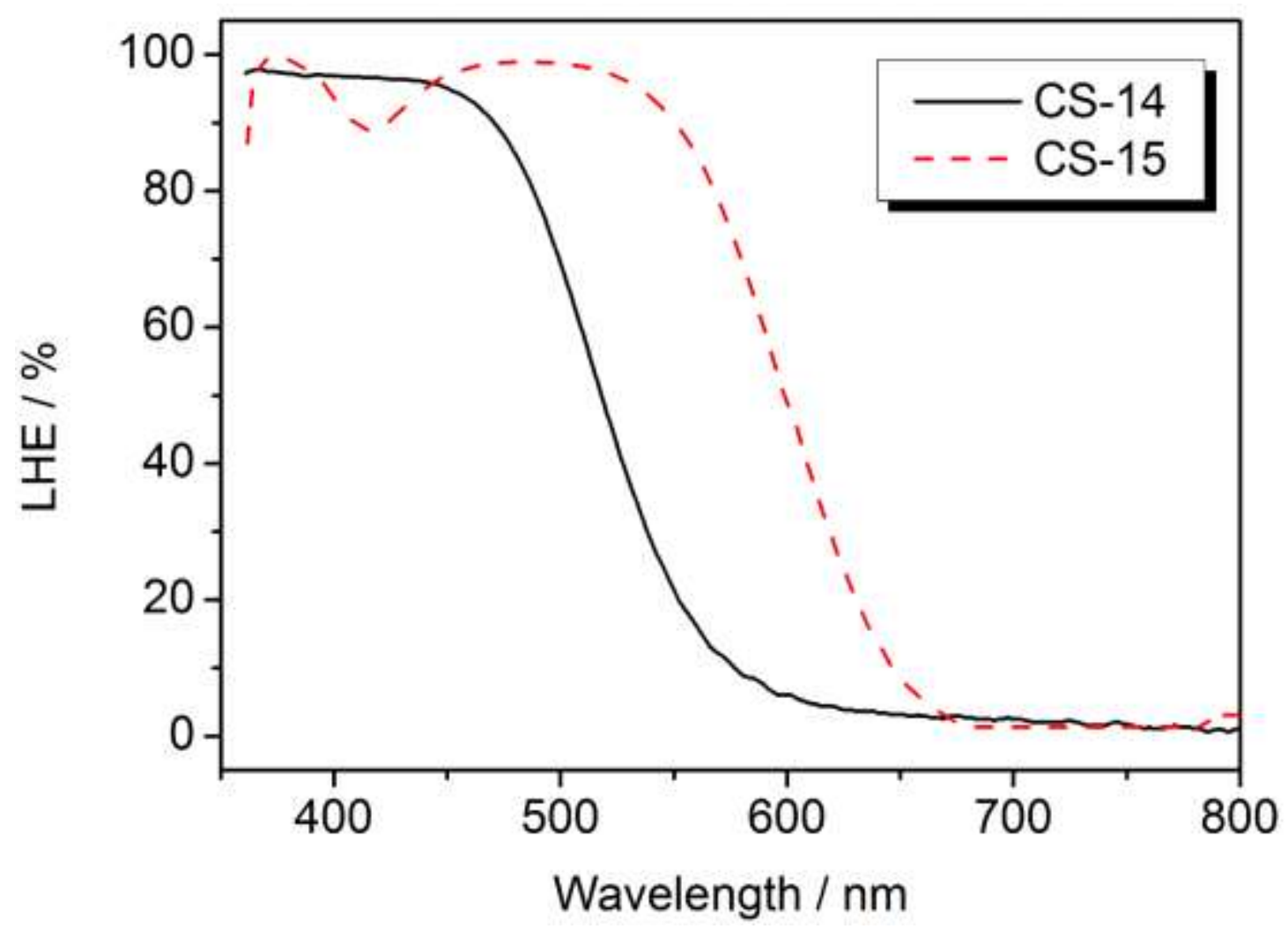

Figure S2 LHE spectra of CS-14 and CS-15 calculated from the absorption spectra of dye-loaded $6 \mu \mathrm{m} \mathrm{TiO}_{2}$ electrodes. 


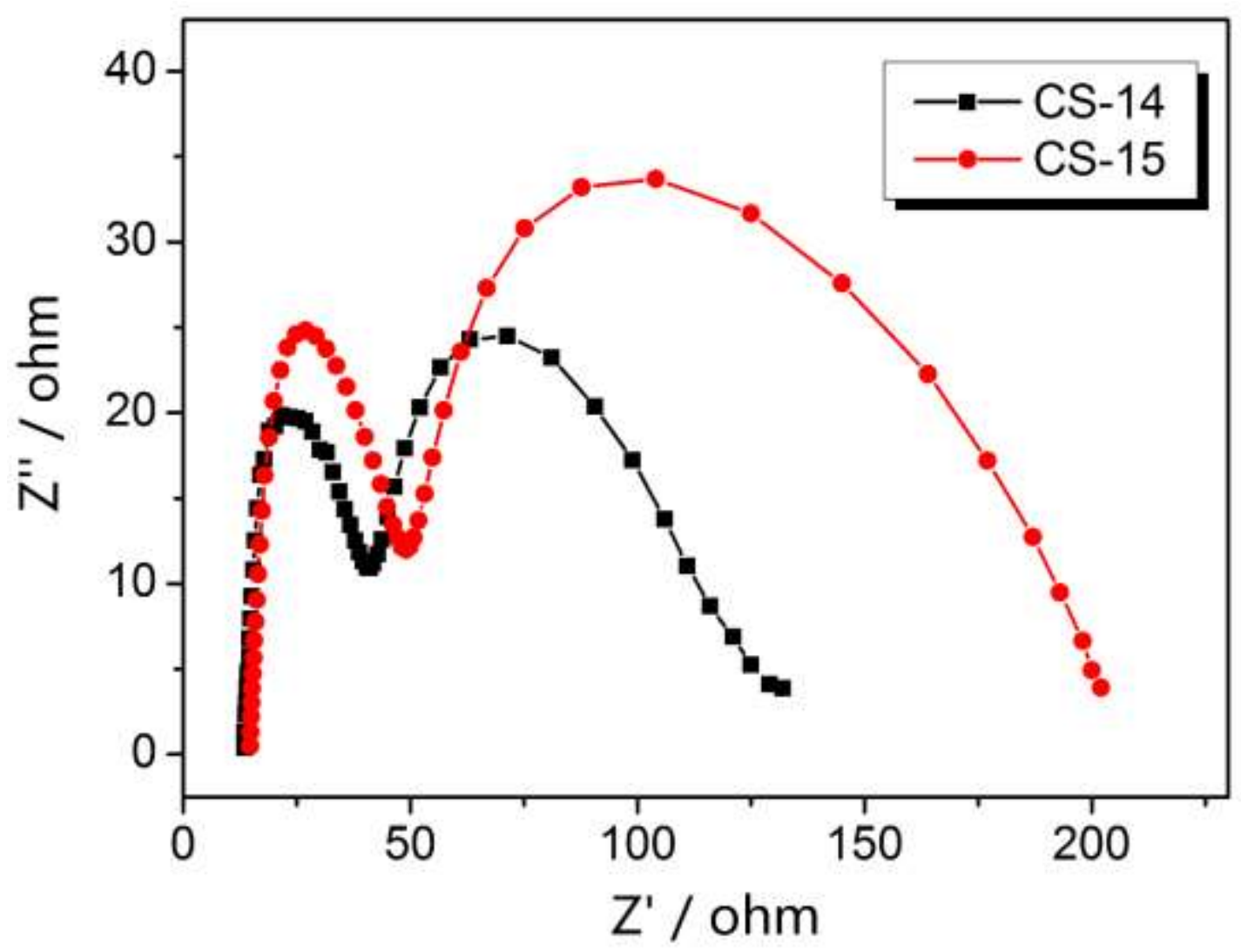

Figure S3 Nyquist plots of CS-14 and CS-15 based DSSCs measured under a dark condition, applying a $10 \mathrm{mV}$ AC sinusoidal modulation superimposed on constant forward bias $(-0.7 \mathrm{~V})$ with the frequency ranging from $10^{5}$ to $10^{-1} \mathrm{~Hz}$. 

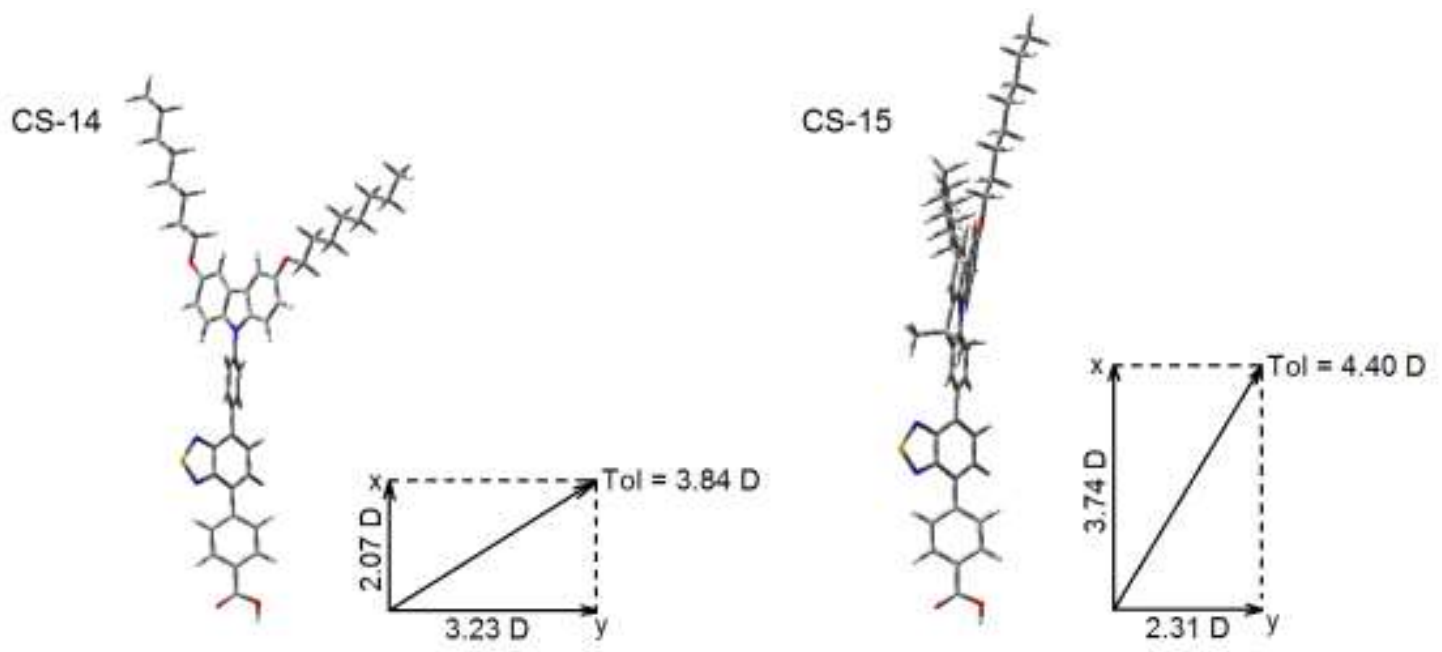

Figure S4 The vertical dipole moments of CS-14 and CS-15 calculated at their optimized geometries of the ground singlet states.

\section{Reference}

1. Zhang, M.; Yao, Z. Y.; Yan, C. C.; Cai, Y. C.; Ren, Y. M.; Zhang, J.; Wang, P., Unraveling the Pivotal Impacts of Electron-Acceptors on Light Absorption and Carrier Photogeneration in Perylene Dye Sensitized Solar Cells. ACS Photonics 2014, 1, 710-717.

2. Nakade, S.; Kanzaki, T.; Wada, Y.; Yanagida, S., Stepped Light-Induced Transient Measurements of Photocurrent and Voltage in Dye-Sensitized Solar Cells: Application for Highly Viscous Electrolyte Systems. Langmuir 2005, 21, 1080310807.

3. Frisch, M. J.; Trucks, G. W.; Schlegel, H. B.; Scuseria, G. E.; Robb, M. A.; Cheeseman, J. R.; Scalmani,G.; Barone, V.; Mennucci, B.; Petersson, G. A., et al. Gaussian 09, Revision B.01; Gaussian, Inc., Wallingford, CT, 2009. 